\title{
Homogeneous Charge Compression Ignition: Formulation Effect of a Diesel Fuel on the Initiation and the Combustion Potential of Olefin Impact in a Diesel Base Fuel
}

\author{
D. Alseda ${ }^{1,2}$, X. Montagne ${ }^{1}$ and P. Dagaut ${ }^{2}$ \\ 1 Institut français du pétrole, IFP, 1-4 avenue de Bois-Préau - 92852 Rueil-Malmaison Cedex - France \\ 2 Centre National de la Recherche Scientifique, 1C avenue de la recherche scientifique, 45071 Orléans Cedex 2 - France \\ e-mail: dorotheealseda@yahoo.fr - xavier.montagne@ifp.fr - dagaut@cnrs-orleans.fr
}

\begin{abstract}
Résumé - Combustion en mode HCCI : impact de la formulation d'un carburant Diesel sur l'initiation et la combustion - Potentiel de l'ajout d'oléfine dans une base gazole - L'objectif de ce travail est de proposer une amélioration du contrôle et de l'initiation de la combustion en mode HCCI via la formulation du carburant. L'article présente l'impact de l'addition d'oléfines (et en particulier l'addition de 1-octène et d'octa-1,7-diène) dans une base gazole. Les tests sont effectués à l'aide d'un réacteur auto-agité et d'un banc moteur. L'indice de cétane d'un carburant Diesel n'est pas réellement adapté pour un contrôle parfait de la combustion en mode HCCI. Dans des conditions de combustion en mode HCCI, l'autoinflammation de la base gazole se produit trop tôt dans le cycle moteur. Cette étude montre, sur réacteur auto-agité, que le 1-octène réduit l'avancement réactionnel de la flamme froide du n-octane. Sur banc moteur, à $1500 \mathrm{tr} / \mathrm{min}$, l'ajout de 1-octène et d'octa-1,7-diène diminue le délai physique et augmente le délai chimique d'auto-inflammation de la base gazole. Ces résultats s'expliquent par la chimie des oléfines : les doubles liaisons des oléfines impliquent des réactions compétitives (avec des radicaux) à celles donnant lieu à la flamme froide. De plus, les espèces intermédiaires sont stabilisées par mésomérie. Au niveau des polluants, les oléfines diminuent les émissions d'HC de la base gazole. Ajouter des oléfines légères à une base gazole est une voie d'amélioration envisageable pour la combustion en mode HCCI.
\end{abstract}

\begin{abstract}
Homogeneous Charge Compression Ignition: Formulation Effect of a Diesel Fuel on the Initiation and the Combustion - Potential of Olefin Impact in a Diesel Base Fuel - In this work, attention is paid on initiation and HCCI combustion control through fuel formulation. This article shows the effect of olefin addition (and in particular 1-octene and octa-1,7-diene addition) in a Diesel base fuel. Tests are made with a jet-stirred reactor and an engine bench. The current Diesel fuel cetane numbers are not really adapted for a perfect control of HCCI combustion. In HCCI conditions, the autoignition of a Diesel fuel occurs too early in the cycle. This study shows that, with the jet-stirred reactor, 1-octene addition allows decreasing the advancement of the cool flame reaction of n-octane. Engine bench experiments show that, at $1500 \mathrm{rpm}, 1$-octene and octa-1,7-diene addition decrease the physical delay and increase the chemical auto-ignition delay of the Diesel base fuel. These results can be explained by olefin chemistry: olefin double bonds imply reactions (with radicals) that are in competition with the cool flame reactions. There is also the fact that the intermediate species are stabilised by mesomery. About pollutants, olefin addition decreases $\mathrm{HC}$ emissions of the Diesel base fuel. Adding light olefins in a Diesel base fuel could improving the HCCI combustion.
\end{abstract}




\section{DEFINITIONS, ACRONYMS, ABBREVIATIONS}

CA Crank angle

$\mathrm{CAX}$ Crank angle degree which corresponds at $X \%$ of the burned fraction

CFR Cooperative fuel research

CO Carbon monoxide

DICI Direct Injection Compression Ignition

fsn Fuel smoke number

HC Unburned hydrocarbon

HCCI Homogeneous charge compression ignition

HTHR High temperature heat release

IMEP Indicated mean effective pressure

JSR Jet-stirred reactor

LTC Low temperature combustion

LTHR Low temperature heat release

NTC Negative temperature coefficient

ppm Part per million

rpm Rotation per minute

TDC Top dead centre

$\tau \quad$ Residence time

$\Phi \quad$ Equivalence ratio

\section{INTRODUCTION}

Ground transportation is responsible for most of the air pollution. To better respect the exhaust emission regulations, new Low Temperature Combustion (LTC) processes such as HCCI engine (Homogeneous Charge Compression Ignition) are currently studied. HCCI process is based on the auto-ignition of a highly diluted air/fuel mixture. The ignition occurs at several locations in the whole combustion chamber. It can reduce significantly $\mathrm{NO}_{\mathrm{x}}$ and particulate exhaust emissions by a factor 10 to 100 [1]. Meanwhile some problems must be solved: the limited combustion range, the difficulty to control the combustion process, the high $\mathrm{HC}$ and $\mathrm{CO}$ emissions and the noise. Engine technology can improve HCCI combustion [2-5] and due to the fact that HCCI combustion occurs at lower temperature than conventional Diesel combustion, another solution to solve these problems is to control HCCI combustion through fuel formulation [2, 6-9].

The subject of this work is in a first step to extend chemistry knowledge for in a second step to improve the control of the initiation and the HCCI combustion through fuel formulation.

It seems to be difficult to have only an "HCCI engine" because the operation zone of the engine is too small. More likely, it will be a DICI/HCCI engine. So, it is necessary to have a fuel formulation adapted for these two combustion modes. To have an optimised combustion with the conventional direct injection compression ignition engine without engine modifications, fuel properties need to be near Diesel base fuel properties. So a Diesel base fuel is chosen for the experiments. It is difficult to have an adapted HCCI combustion with a Diesel base fuel because the combustion occurs too early in the cycle [10-12]. Components are added in the Diesel base fuel to try to better control the combustion. The components are used as a refinery blending components and no as an on-board second fuel. There are several ways to improve the HCCI combustion thanks to the fuel formulation like aromatic addition. For this study, the components chosen are olefins. Olefins are chosen for their kinetic of oxidation and their oxidation products. The particularity of olefins is to be unsaturated (presence of C-C double bond). In chemistry, the double bond of olefins implies a higher reactivity than that of paraffin. However, they have a cetane index lower than the corresponding alkanes. These two aspects, which seem to be contradictory, show the interest to test olefin addition in HCCI conditions. It allows seeing if, in HCCI conditions, the aspect "reactivity higher" or "cetane index lower" control the impact of olefin addition.

For this work, two experimental tools are used: a jetstirred reactor and a single cylinder engine. Of course a comparison between the jet-stirred reactor and the engine experiments is not directly possible because the experimental conditions are very different and it is not the aim of this article. First, the jet stirred reactor experiments allow to see if the double bond of the olefin can have an effect on the cool flame. Then engine experiments allow studying the influence of fuel formulation with olefins in real conditions.

\section{EXPERIMENTAL DETAILS AND PROCEDURE}

\subsection{Jet Stirred Reactor (JSR)}

\subsubsection{Experimental Details}

The experimental setup described previously [13] is used. The JSR is a $4 \mathrm{~cm}$ diameter fused-silica sphere. The inside volume is $39 \mathrm{~cm}^{3}$. The reactor is equipped of 4 nozzles of $1 \mathrm{~mm}$ diameter admitting the gases which achieve the stirring. It is surrounded by two independent insulated heating wires and located inside a stainless steel pressure resistant jacket filled with insulating material. It can operate at pressures as high as 40 bar. A regulated nitrogen flow in the outer part of the reactor balances the pressure inside the reaction cell. Previous residence time distribution studies, using pulse injection of a tracer, have demonstrated that this type of reactor is well-stirred for residence times of $10 \mathrm{~ms}$ to several seconds, depending on the total pressure in the range 1-10 bar [14]. All the gases are delivered by mass flow controllers. The liquid fuel is delivered by an HPLC pump to a homemade vaporiser providing a homogeneous nitrogen-fuel mixture flowing through a capillary, up to the mixing point at the 
top of the reactor, to prevent reactions before the entrance of the reactor. A nitrogen flow of $100 \mathrm{~L} / \mathrm{h}$ is used to dilute the fuel. The reactants flow continually in the reactor. A high degree of dilution is used $(0.1 \%$ of fuel $)$ in order to reduce temperature gradients and heat release in the reaction cell, thus operating at steady state is possible. It should be noted that no flame occurs in the JSR, due to dilution. All the gases are preheated before injection in order to reduce temperature gradients in the JSR. A $12.5 \mathrm{~kW}$ induction heating system is used. Two regulated heating wires of $1 \mathrm{~kW}$ each are used to maintain the temperature of the upper and lower part of the reaction cell to the desired temperature. The upper part of the capillary is also temperature-regulated in order to avoid condensation of the fuel. The good homogeneity of the reactor cell is checked by moving a thermocouple (Pt-PT/Rh 10\% wires of $0.13 \mathrm{~mm}$ of diameter located inside a thin-wall fused-silica housing) and a sonic quartz probe along the whole vertical axis of the JSR. No temperature gradients, inside the reactor, higher than $10 \mathrm{~K}$ (typically $2-5 \mathrm{~K}$ ) are allowed in these experiments and no concentration gradients are observed. The samples are taken at steady temperature.

In this work, gas chromatography and different detectors are used for the analyses of oxidation products. $\mathrm{HC}$ are measured by a FID (Flame Ionisation Detector); $\mathrm{CO}_{2}, \mathrm{CO}$ and $\mathrm{CH}_{2} \mathrm{O}$ after been methanised by a FID; $\mathrm{O}_{2}$ and $\mathrm{H}_{2}$ by a TCD (Thermal Conductivity Detector).

\subsubsection{Experimental Conditions}

The jet-stirred reactor experiments allow studying the influence of 1-octene addition on the oxidation of n-octane. Due to its high distillation range, the Diesel base fuel can not be tested with the jet-stirred reactor, so n-octane is preferred. Experiments are performed at 10 bar, for a mean residence time of $1 \mathrm{~s}$, at equivalence ratio equal to 1 , temperature varies from $580 \mathrm{~K}$ to $1080 \mathrm{~K}$.

The wide temperature range considered allows the observation of the cool flame, the negative temperature coefficient (NTC) and the hot flame.

\subsection{Engine Bench}

\subsubsection{Experimental Details}

The engine used is a direct-injection single-cylinder engine based on a standard Audi V6 engine with a Bosch common rail injection system. A Bosch injector with 6 holes (diameter $=0.14 \mathrm{~mm}$, permeability $=340 \mathrm{~mL} / 30 \mathrm{~s}$ at $100 \mathrm{bar}$ ) is used. The injection rail pressure and the injection phasing are controlled electronically. The engine is based on the NADI ${ }^{\mathrm{TM}}$ (Narrow Angle Direct Injection) concept developed by IFP [15]: the spray cone angle is at $60^{\circ}$.
The EGR rate is measured with the Pierburg AMA 2000 gas analyser.

The in-cylinder pressure is measured using an AVL $(\mathrm{QH} 33 \mathrm{D})$ pressure transducer and the heat release rate and the temperature by a software based on the thermodynamic laws, internal to IFP.

The main engine characteristics are given in Table 1.

TABLE 1

Engine experimental details

\begin{tabular}{l|c}
\hline Bore & $78 \mathrm{~mm}$ \\
\hline Stroke & $86 \mathrm{~mm}$ \\
\hline Displacement & $416 \mathrm{~cm}^{3}$ \\
\hline Compression ratio & $15: 1$ \\
\hline Swirl ratio & 1.3 \\
\hline
\end{tabular}

The engine control is made thanks to Emtronics for the control of the injection parameters and Klepcat for the acquisition of the measures.

Air is supplied thanks to a system of sonic throat. The air flow rate is made with the section of the throat.

The temperatures are measured (in the plenum and in the engine) using $\mathrm{K}$ thermocouples.

The noise is calculated thanks to the average of the 100 cycles of the in-cylinder pressure, with an AVL noise meter and the soot with an AVL smoke meter 415.

The equivalence ratio is calculated thanks to the analysis of the $\mathrm{CO}, \mathrm{CO}_{2}, \mathrm{HC}, \mathrm{NO}_{\mathrm{x}}$ and $\mathrm{O}_{2}$ emissions.

The equivalence ratio is calculated thanks to the equation:

$R=1+3.764 \times \frac{A-B}{C}$

with $A=\mathrm{CO}(\%)+\mathrm{CO}_{2}(\%)+\frac{\mathrm{HC}(\mathrm{ppmC})}{10^{4}(\mathrm{ppm} / \%)}$

$$
B=\frac{(1-0.3) \times \mathrm{CO}(\%)}{2}+\mathrm{CO}_{2}(\%)+\mathrm{O}_{2}(\%)-
$$

$\frac{1}{4} \times \mathrm{H} / \mathrm{C} \times \frac{\mathrm{HC}(\mathrm{ppmC})}{10^{4}(\mathrm{ppm} / \%)}+E N \times 0.5 \times \frac{\mathrm{NO}_{\mathrm{x}}(\mathrm{ppm})}{10^{4}(\mathrm{ppm} / \%)}$

$C=100-E-(1+0.3) \times \mathrm{CO}(\%)-\mathrm{CO}_{2}(\%)-\mathrm{O}_{2}(\%)-$

$\frac{1}{7} \times \frac{\mathrm{HC}(\mathrm{ppmC})}{10^{4}(\mathrm{ppm} / \%)}-\frac{1}{2} \times \frac{\mathrm{NO}_{\mathrm{x}}(\mathrm{ppm})}{10^{4}(\mathrm{ppm} / \%)}$

with $E N=1.2$ (this is an approximation of the part of $\mathrm{NO}_{2}$ in $\mathrm{NO}_{\mathrm{X}}$ ), $E$ is the relative humidity after the drying. 


\subsubsection{Fuel Formulation}

The Diesel fuel as the reference fuel for the experiments is a current EN590 Diesel fuel. The main Diesel fuel properties are given in the Table 2 .

TABLE 2

Diesel base fuel properties

\begin{tabular}{l|c}
\hline Cetane number & 53.5 \\
\hline Density & 0.836 \\
\hline Distillation range & $173^{\circ} \mathrm{C}-352^{\circ} \mathrm{C}$ \\
\hline Carbon content & $86.4 \%$ \\
\hline Hydrogen content & $13.5 \%$ \\
\hline Oxygen content & $<0.2 \%$ \\
\hline Sulphur content & $<50 \mathrm{ppm}$ \\
\hline
\end{tabular}

Figure 1 gives the chemical analyse of the Diesel base fuel.

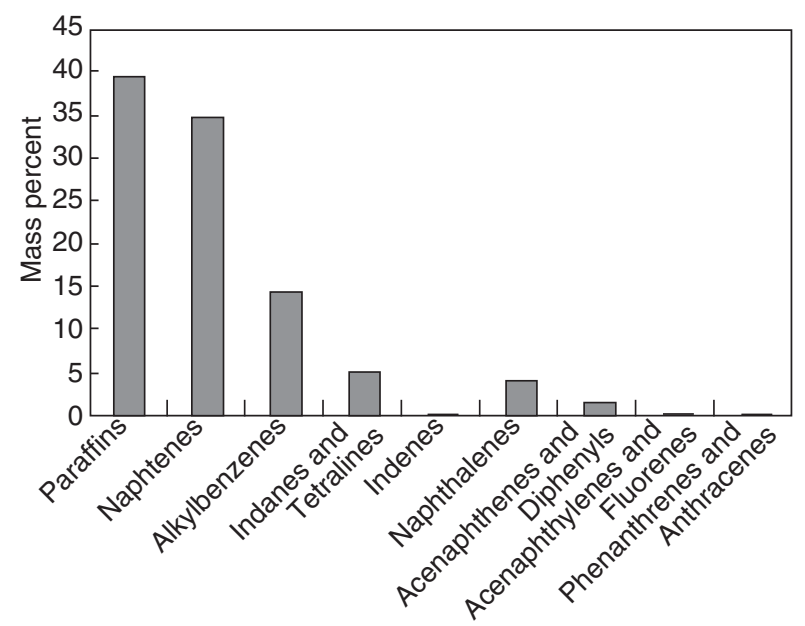

Figure 1

Chemical analyse of the Diesel base fuel.

The single well known components added to improve the HCCI combustion of the Diesel base fuel are olefins: 1octene and octa-1,7-diene (Fig. 2). A di-olefin is chosen to study the influence of two C-C double bonds on HCCI combustion.

$10 \%$ (volumetric percent) of 1-octene and octa-1,7-diene are added in the Diesel base fuel.

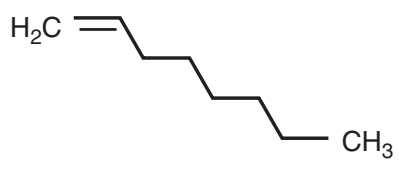

1-octene

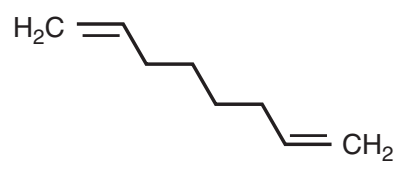

octa-1,7-diene
Figure 2

Molecule representations.

Table 3 gives the boiling point and the auto-ignition temperature of 1-octene and octa-1,7-diene. Table 4 gives the cetane number of the Diesel base fuel/olefin blends. The cetane numbers of the fuels are measured with a CFR engine.

TABLE 3

1-octene and octa-1,7-diene characteristics

\begin{tabular}{l|c|c}
\hline & 1 -octene & octa-1,7-diene \\
\hline Boiling point & $120^{\circ} \mathrm{C}$ & $115^{\circ} \mathrm{C}$ \\
\hline Auto-ignition temperature & $260^{\circ} \mathrm{C}$ & $230^{\circ} \mathrm{C}$ \\
\hline Density (at $\left.25^{\circ} \mathrm{C}\right)$ & $0.715 \mathrm{~g} / \mathrm{cm}^{3}$ & $0.746 \mathrm{~g} / \mathrm{cm}^{3}$ \\
\hline Viscosity (at $\left.20^{\circ} \mathrm{C}\right)$ & $0.613 \mathrm{cp}$ & $0.5 \mathrm{cp}$ \\
\hline Cetane number & 41.3 & Not measured \\
\hline
\end{tabular}

TABLE 4

Cetane number of the Diesel base fuel/olefin blends

\begin{tabular}{lc}
\hline & Cetane number \\
\hline Diesel fuel & 53.5 \\
\hline Diesel base fuel/1-octene (90/10) & 49.4 \\
\hline Diesel base fuel/octa-1,7-diene (90/10) & 49.3 \\
\hline
\end{tabular}

\subsubsection{Engine Experimental Methodology}

The Diesel fuel combustion experiments are optimised with a respect of three criteria: noise, smoke index and $\mathrm{NO}_{\mathrm{x}}$ levels (Table 5).

\section{TABLE 5}

Noise, smoke index and $\mathrm{NO}_{\mathrm{x}}$ levels $\mathrm{HCCI}$ criteria

\begin{tabular}{l|c|c}
\hline & $1500 \mathrm{rpm}$ & $2500 \mathrm{rpm}$ \\
\hline Maximum noise allowed (dB) & 86 & 90 \\
\hline Maximum smoke index allowed (fsn) & 2 & 2 \\
\hline Maximum $\mathrm{NO}_{\mathrm{x}}$ allowed $(\mathrm{g} / \mathrm{kWh})$ & 0.1 & 0.1 \\
\hline
\end{tabular}


These experiments allow obtaining a reference set-up. This reference set-up is then used for the two blends Diesel fuel/olefin. The different fuels have different properties so it is not possible to keep constant all the parameters therefore the overall equivalence ratio and fuel flow are kept constant and the IMEP (Indicated Mean Effective Pressure) can vary (Table 6). To keep the overall equivalence ratio at constant for neat Diesel base fuel and blends fuels, the air flow is modified.

TABLE 6

IMEP variation for each fuel

\begin{tabular}{l|c|c|c|c}
\hline & \multicolumn{2}{|c|}{1500 rpm } & \multicolumn{2}{c}{$2500 \mathrm{rpm}$} \\
\hline & $\begin{array}{c}\text { IMEP } \\
\sim 3 \text { bar }\end{array}$ & $\begin{array}{c}\text { IMEP } \\
\sim 6 \text { bar }\end{array}$ & $\begin{array}{c}\text { IMEP } \\
\sim 3 \text { bar }\end{array}$ & $\begin{array}{c}\text { IMEP } \\
\sim 6 \text { bar }\end{array}$ \\
\hline Diesel base fuel & 3 & 5.97 & 2.99 & 6 \\
\hline Diesel base fuel/1-octene (90/10) & 2.99 & 6.01 & 2.81 & 5.72 \\
\hline Diesel base fuel/octa-1,7-diene (90/10) & 2.93 & 6 & 2.84 & 5.81 \\
\hline
\end{tabular}

\subsubsection{Experimental Conditions}

Four operating conditions are tested. For each operating conditions two or three injections per cycle are applied:

$-1500 \mathrm{rpm} \times \mathrm{IMEP}=3 \mathrm{bar}$, equivalence ratio $=0.7$, 2 injections before TDC: 1 st injection at $55 \mathrm{CA}$ and 2 nd at 25 CA.

$-1500 \mathrm{rpm} \times \mathrm{IMEP}=6$ bar, equivalence ratio $=0.81$, 3 injections before TDC: 1 st injection at $90 \mathrm{CA}, 2 \mathrm{nd}$ at $60 \mathrm{CA}$ and 3rd at $20 \mathrm{CA}$.

$-2500 \mathrm{rpm} \times$ IMEP $=3$ bar, equivalence ratio $=0.61$, 2 injections before TDC: 1 st injection at $40 \mathrm{CA}$ and 2 nd injection at $17 \mathrm{CA}$.

$-2500 \mathrm{rpm} \times$ IMEP $=6$ bar, equivalence ratio $=0.84$, 3 injections before TDC: 1 st injection at $100 \mathrm{CA}$, 2nd injection at $70 \mathrm{CA}$ and 3rd injection at $30 \mathrm{CA}$.

\subsubsection{Fuel Formulation Adapted for the HCCI Combustion}

Figure 3 shows the important points for the HCCI combustion: the initiation, the CA10 (crank angle degree which corresponds at $10 \%$ of the burned fraction), the peak of the HTHR, the CA50 (crank angle degree which corresponds at $50 \%$ of the burned fraction) and the CA90 (crank angle degree which corresponds at $90 \%$ of the burned fraction). They are important because their positions in the cycle can help to improve the HCCI combustion.

Five points, at $1500 \mathrm{rpm} / \mathrm{IMEP}=3 \mathrm{bar}$ and $1500 \mathrm{rpm} / \mathrm{IMEP}$ $=6$ bar, were made to study the impact of the initiation, the CA50-CA10 and the CA90-CA_HTHR on $\mathrm{NO}_{\mathrm{x}}$ emissions, smoke emissions and the noise (Figs. 4, 7).

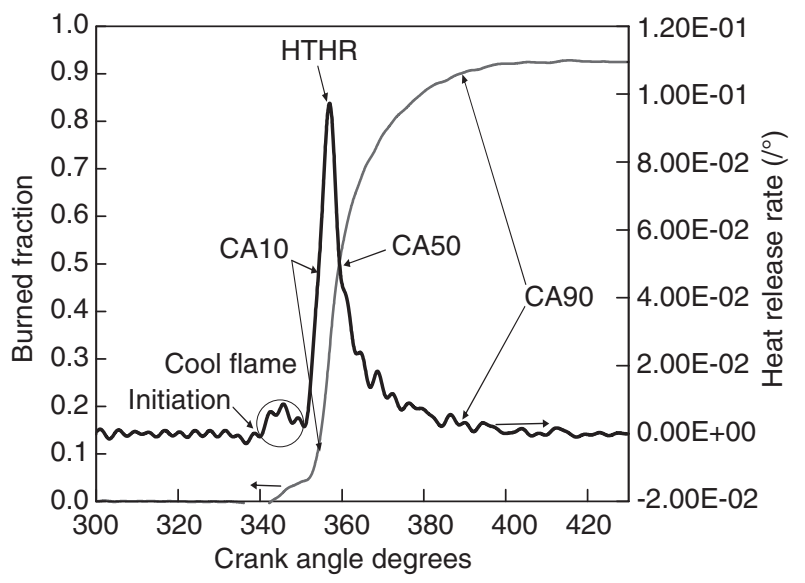

Figure 3

Important points for the HCCI combustion.

To improve the HCCI combustion of a Diesel base fuel:

- The physical delay, which corresponds to the vaporisation of the fuel, must be short to improve the homogenisation of the air/fuel mixture and to better control the initiation of the combustion. In this work the physical delay is not directly measured but it is associated to the addition of lighter fractions in the Diesel base fuel.

- The initiation must be delayed in the cycle. It allows having a better homogenisation of the air/fuel mixture and to decrease $\mathrm{NO}_{\mathrm{x}}$ and smoke emissions (Figs. 4, 5).

- The combustion propagation time between the CA10 and the CA50 must increase. It allows to decrease the pressure gradient and so to decrease the noise (Fig. 6).

- The time of the end of the combustion between the peak of the HTHR (CA_HTHR) and the CA90 must decrease. It allows to help smoke post oxidation and so to decrease smoke emissions (Fig. 7). It allows also keeping good engine efficiency.

Figure 8 is a schematic representation of the modifications needed to improve the HCCI combustion.

\section{RESULTS}

First jet-stirred reactor experiments allow visualising double bond effect on the cool flame. Then engine experiments allow to study 1-octene and octa-1,7-diene effects on the HCCI combustion of a Diesel base fuel.

\subsection{Jet-Stirred Reactor Experiments}

Figure 9 shows the evolution of $\mathrm{CO}$ and $\mathrm{CO}_{2}$ mole fractions versus temperature during the oxidation of 


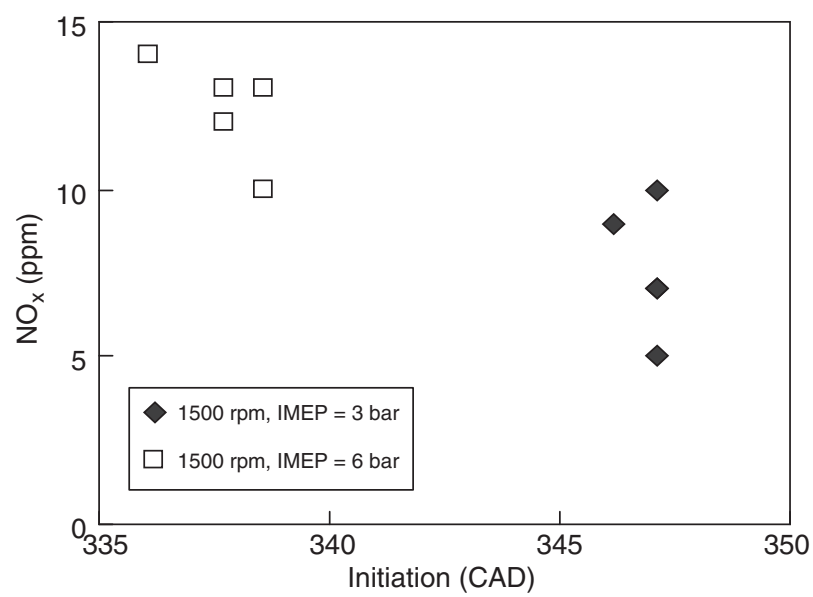

Figure 4

$\mathrm{NO}_{\mathrm{x}}$ emissions versus initiation of the combustion.

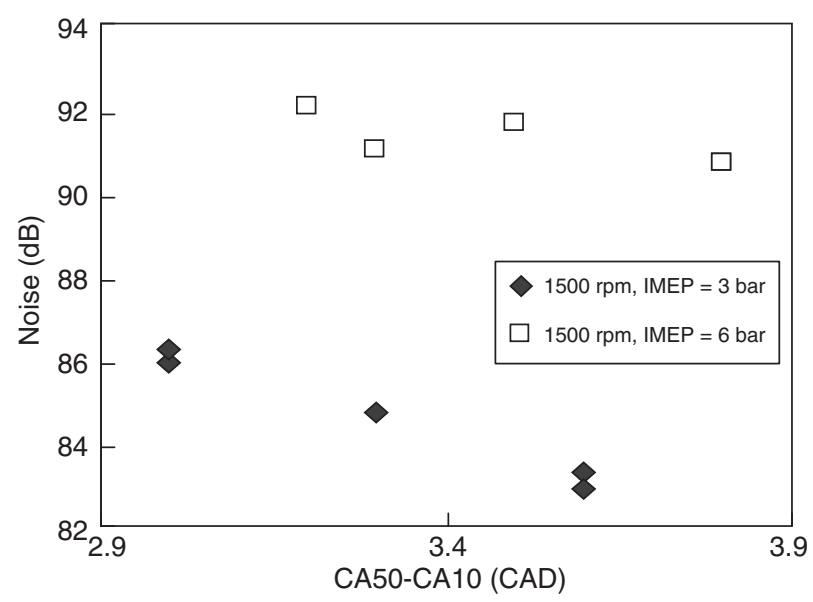

Figure 6

Noise versus combustion propagation time between the CA10 and the CA50.

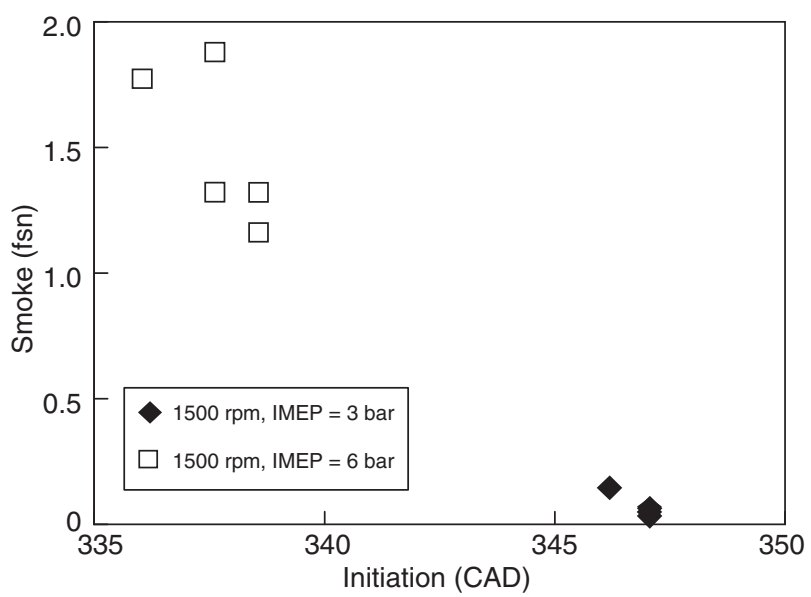

Figure 5

Smoke emissions versus initiation of the combustion.

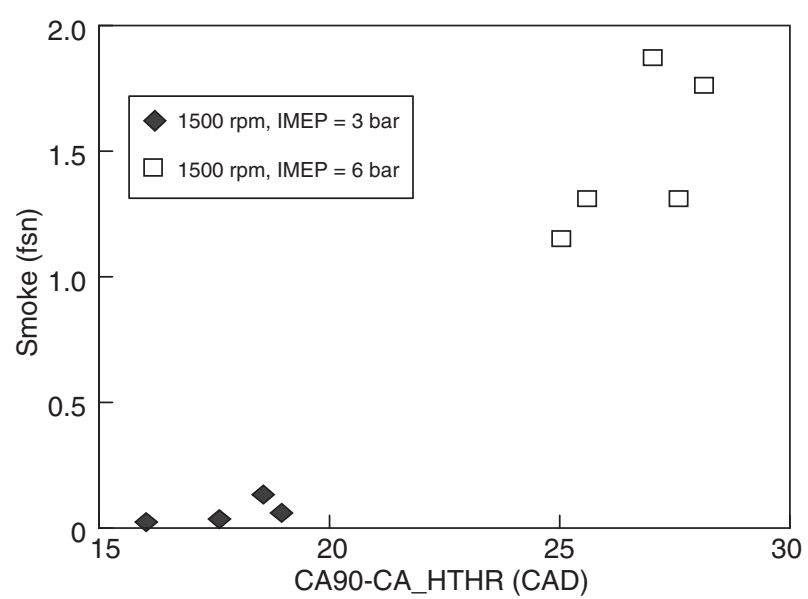

Figure 7

Smoke emissions versus time of the end of the combustion between the peak of the HTHR (CA_HTHR) and the CA90. pure n-octane and n-octane/1-octene 75/25 (volumetric percent) blend in a jet-stirred reactor operating at $P=10$ bar, $\tau=1 \mathrm{~s}$ and $\Phi=1$. The advantage of a study with the jet-stirred reactor is that the conditions are well controlled. It allows studying the fuel conversion and olefin effects on n-octane oxidation.

Figure 9 shows that 1-octene addition decreases the advancement of the cool flame reaction of n-octane.

Olefin addition seems to be a good way to improve HCCI combustion by delaying the initiation of the combustion.

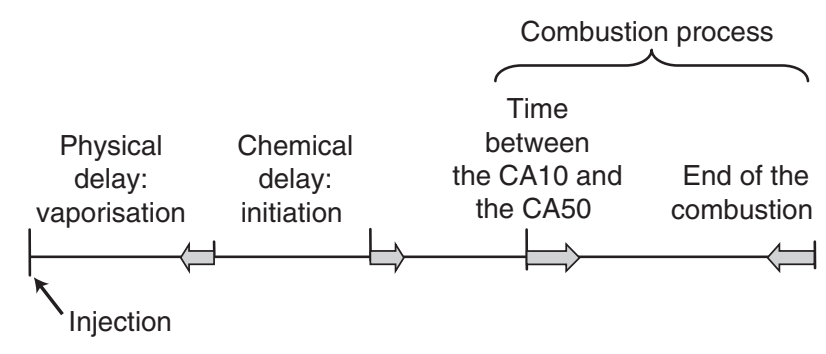

Figure 8

Schematic representation of the modifications needed to improve the HCCI combustion. 


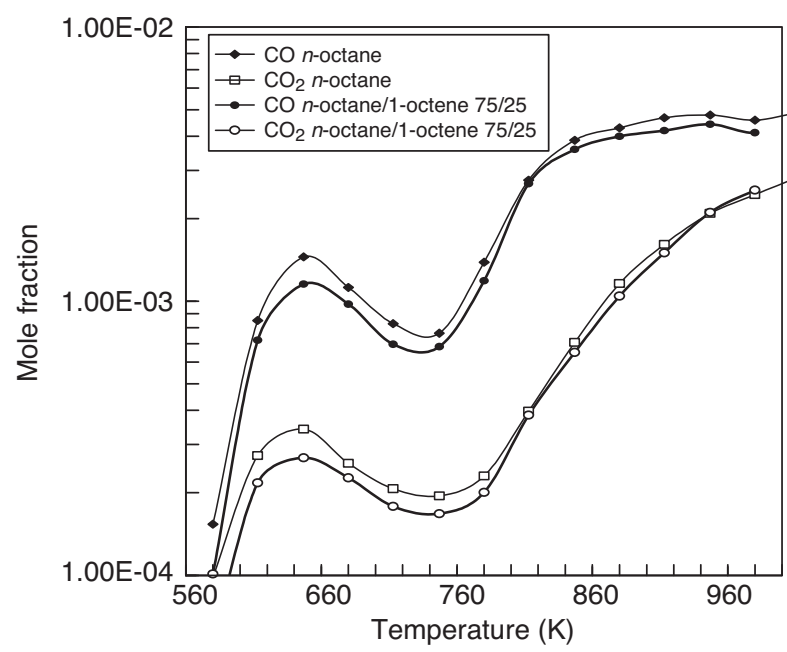

Figure 9

$\mathrm{CO}$ and $\mathrm{CO}_{2}$ mole fractions versus temperature for the oxidation of n-octane and n-octane/1-octene 75/25 blend.

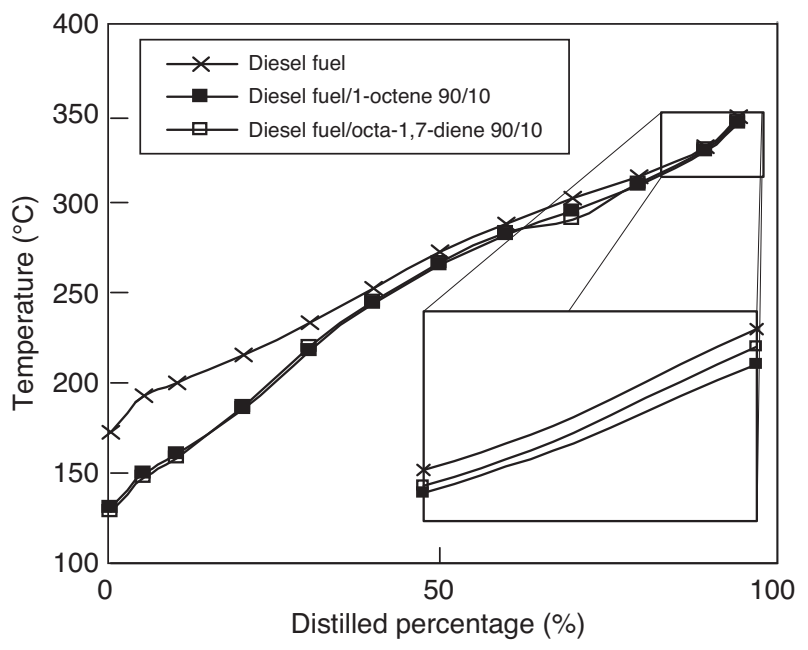

Figure 10

Olefin impact on the distillation range of the Diesel base fuel.

\subsection{Engine Bench}

In the next figures, the errors represent the standard deviation.

\subsubsection{Olefin Impact on the Distillation Range of the Diesel Base Fuel}

Olefin impact on the physical delay of the Diesel base fuel is not directly measured but it is associated to the impact of olefin addition on the distillation range of the Diesel base fuel. Olefin addition decreases in temperature the distillation range of the Diesel base fuel (Fig. 10).

\subsubsection{Olefin Impact on the Initiation of the Combustion}

Figure 11 and Figure 12 show olefin effects on the initiation of the combustion at $1500 \mathrm{rpm} \times \mathrm{IMEP}=3$ and 6 bar and at $2500 \mathrm{rpm} \times \mathrm{IMEP}=3$ and 6 bar.

At $1500 \mathrm{rpm}$, olefin addition delays the initiation of the combustion of the Diesel base fuel (Fig. 11). At $2500 \mathrm{rpm}$, there is no significant effect (Fig. 12).

\subsubsection{Olefin Impact on the Combustion Propagation Time Between the CA10 and the CA50}

Figure 13 and Figure 14 show olefin effects on the combustion propagation time between the CA10 and the CA50 at $1500 \mathrm{rpm} \times$ IMEP $=3$ and 6 bar and at $2500 \mathrm{rpm} \times$ IMEP $=3$ and 6 bar.

At $1500 \mathrm{rpm} \times \mathrm{IMEP}=3$ bar, olefin addition increases the combustion propagation time between the CA10 and the CA50. At $1500 \mathrm{rpm} \times \mathrm{IMEP}=6 \mathrm{bar}$, there is no significant effect (Fig. 13). At $2500 \mathrm{rpm}$, olefin addition decreases the combustion propagation time between the CA10 and the CA50 (Fig. 14).

\subsubsection{Olefin Impact on the Time of the End of the Combustion Between the Peak of the HTHR and the CA90}

Figure 15 and Figure 16 show olefin effects on the time of the end of the combustion between the peak of the HTHR and the CA90 at $1500 \mathrm{rpm} \times$ IMEP $=3$ and 6 bar and at $2500 \mathrm{rpm} \times \mathrm{IMEP}=3$ and 6 bar.

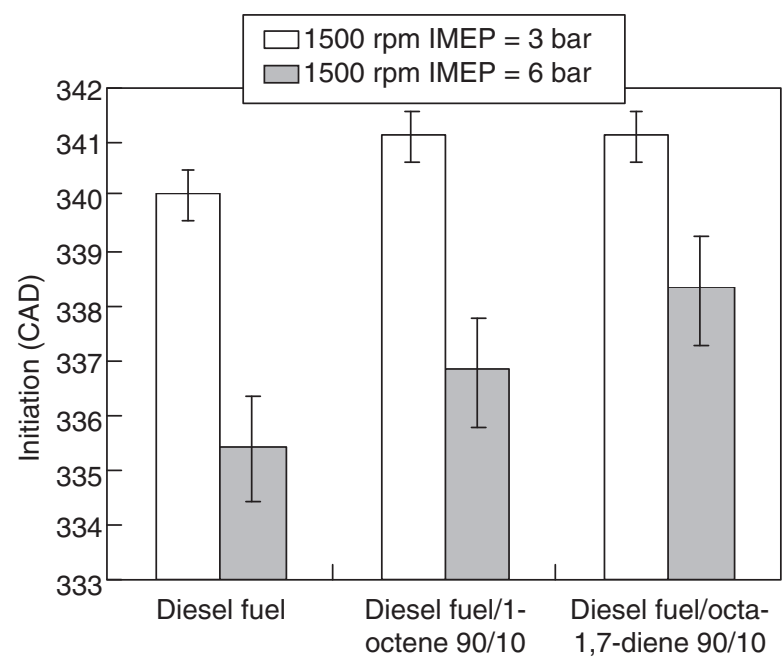

Figure 11

Olefin effect on the initiation of the combustion of the Diesel base fuel at $1500 \mathrm{rpm}$. 


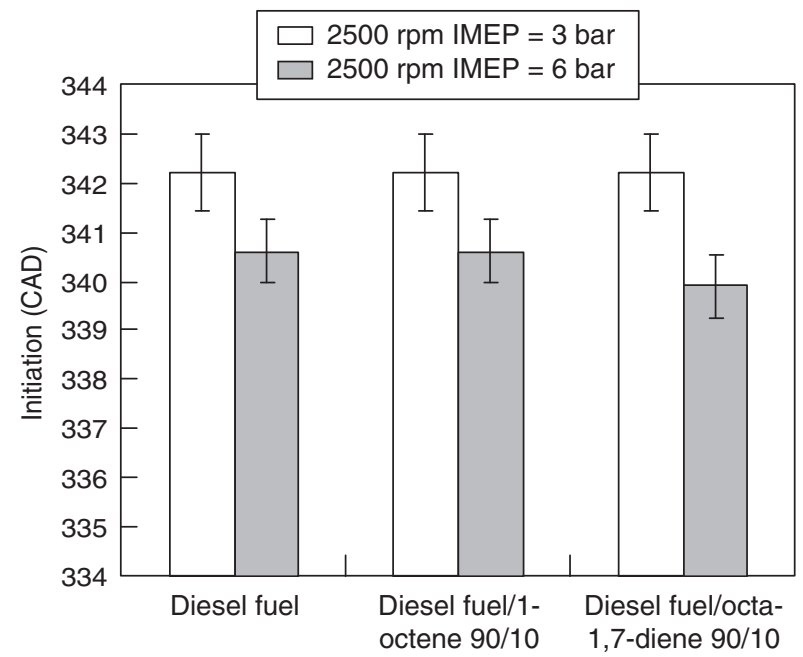

Figure 12

Olefin effect on the initiation of the combustion of the Diesel base fuel at $2500 \mathrm{rpm}$.

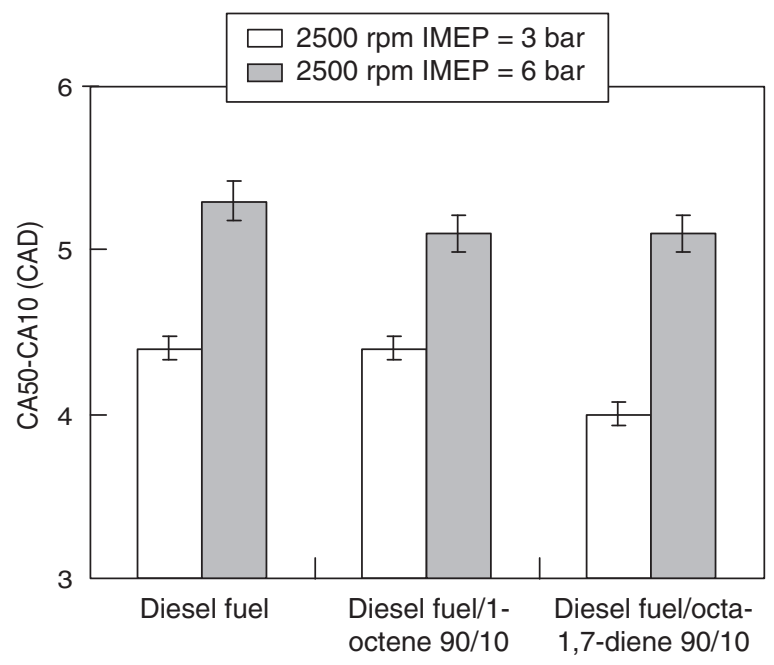

Figure 14

Olefin effect on the combustion propagation time between the CA10 and the CA50 of the Diesel base fuel at $2500 \mathrm{rpm}$.

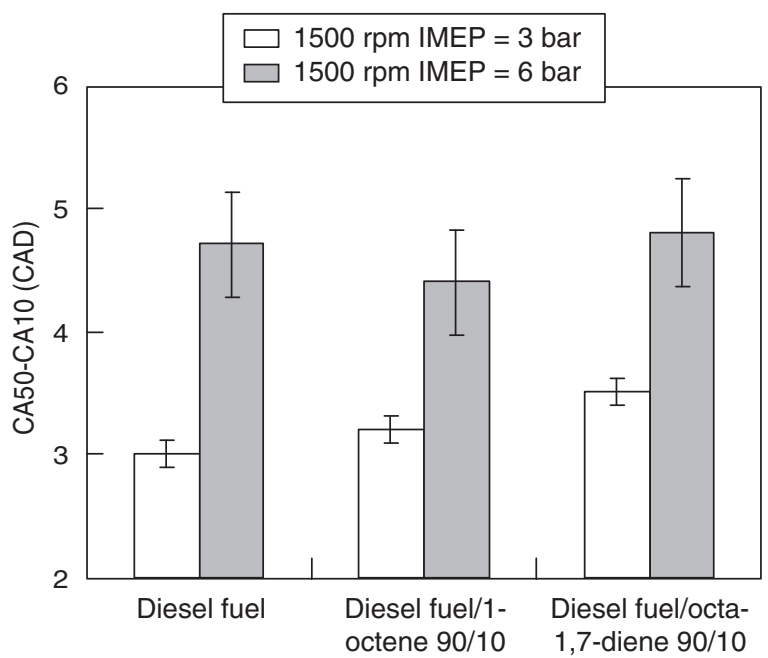

Figure 13

Olefin effect on the combustion propagation time between the CA10 and the CA50 of the Diesel base fuel at $1500 \mathrm{rpm}$.

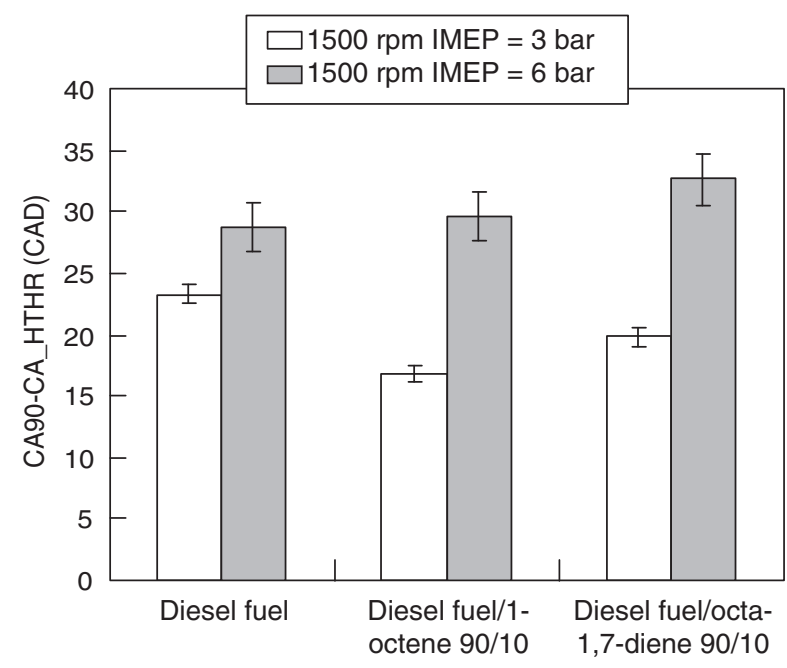

Figure 15

Olefin effect on the time of the end of the combustion between the peak of the HTHR and the CA90 of the Diesel base fuel at $1500 \mathrm{rpm}$.
At $1500 \mathrm{rpm} \times$ IMEP $=3 \mathrm{bar}$, olefin addition decreases the time of the end of the combustion between the peak of the HTHR and the CA90. At IMEP $=6$ bar, olefin addition increases the time of the end of the combustion but results are in the variability of the Diesel base fuel measurements (Fig. 15). At $2500 \mathrm{rpm} \times \mathrm{IMEP}=3$ bar, olefin addition increases the time of the end of the combustion between the peak of the HTHR and the CA90 and at 6 bar, it decreases the time of the end of the combustion (Fig. 16).

\subsubsection{Olefin Impact on the Noise and the Pollutants of a Diesel Base Fuel}

Figure 17 shows olefin addition impact on the noise. The significant values are for the point $1500 \mathrm{rpm} \times \mathrm{IMEP}=3$ bar: olefin addition allows decreasing the noise. This is connected to the evolution of the combustion propagation time between the CA10 and the CA50 (Figs. 18, 19).

Figure 20 to Figure 22 show olefin addition impact on smoke emissions. The comportment of olefin addition on 


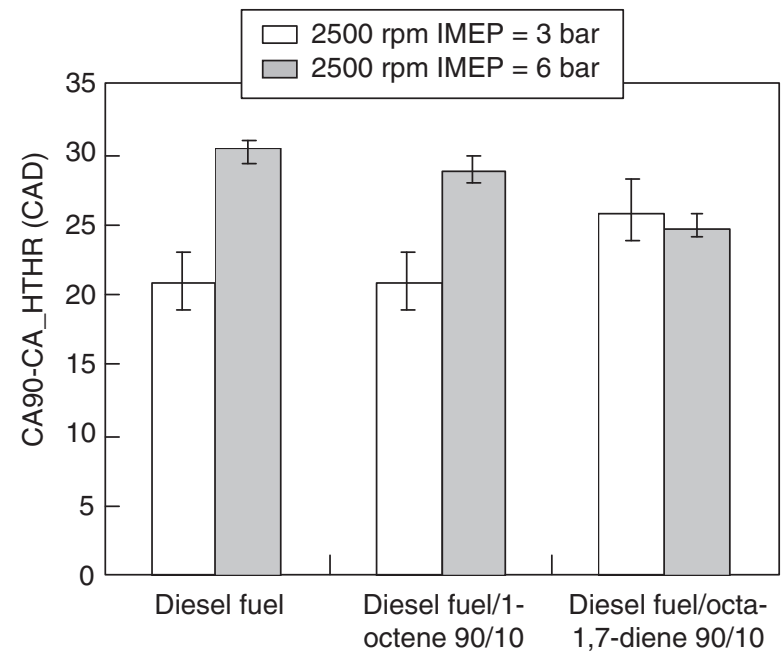

Figure 16

Olefin effect on the time of the end of the combustion between the peak of the HTHR and the CA90 of the Diesel base fuel at $2500 \mathrm{rpm}$.

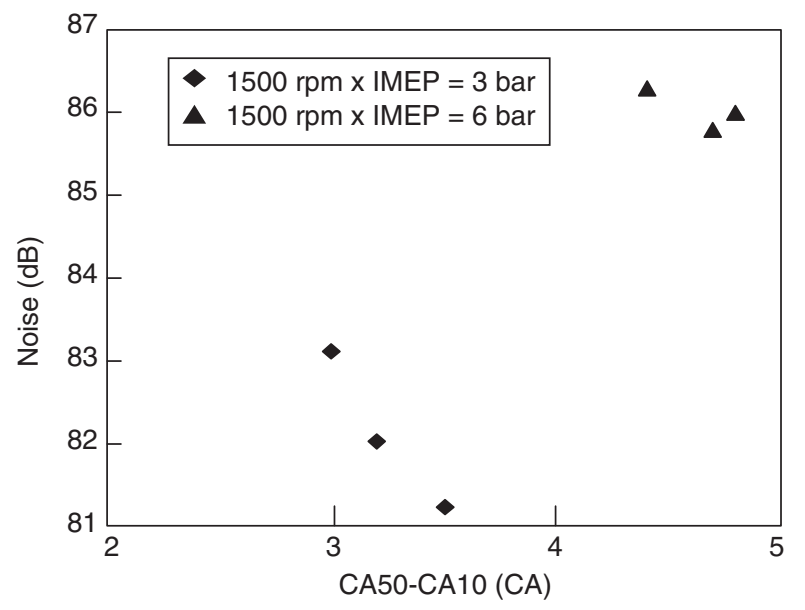

Figure 18

Noise versus CA50-CA10 at $1500 \mathrm{rpm}$.

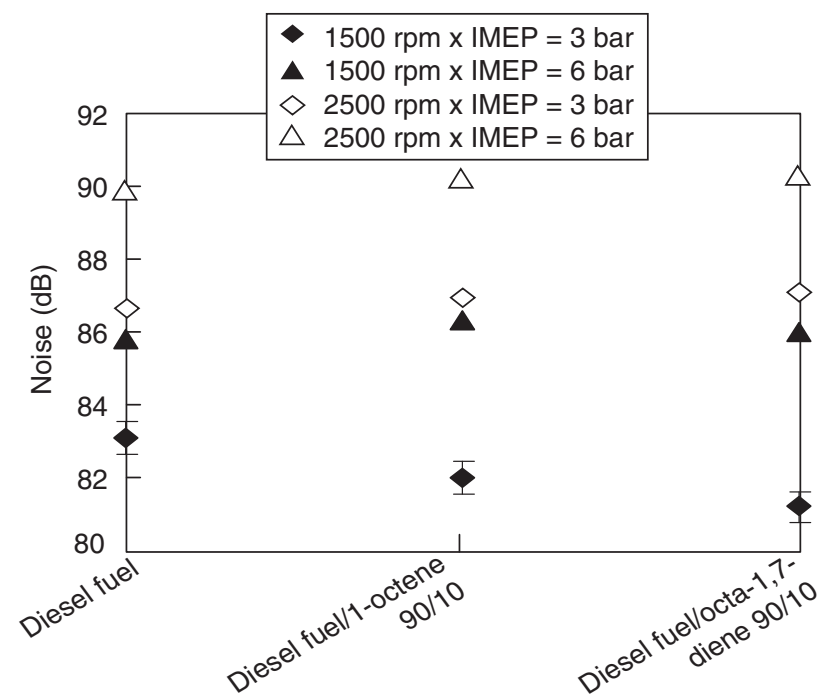

Figure 17

Olefin effect on the noise.

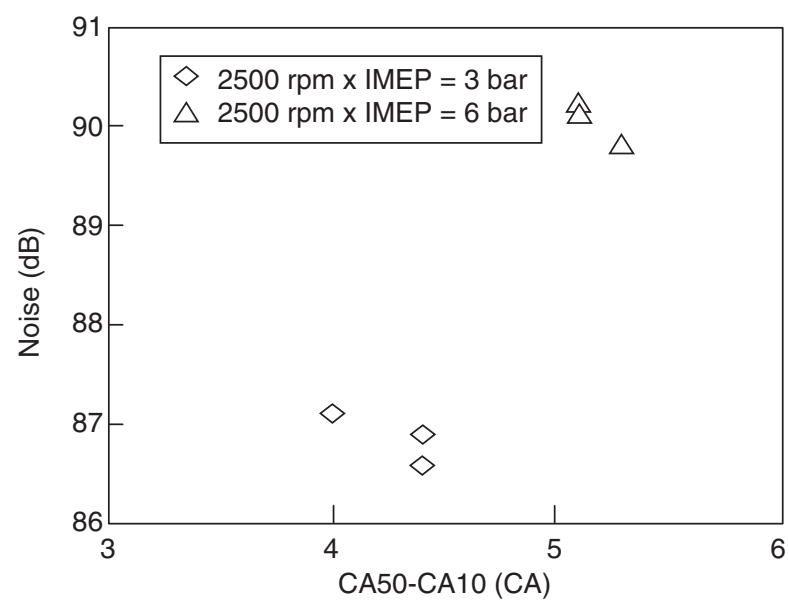

Figure 19

Noise versus CA50-CA10 at $2500 \mathrm{rpm}$. smoke emissions is different for each point and is linked to the evolution of the time of the end of the combustion between the HTHR and the CA90 (Figs. 15, 16).

Figure 23 to Figure 26 show olefin addition impact on $\mathrm{NO}_{\mathrm{x}}$ emissions. Olefin addition decreases $\mathrm{NO}_{\mathrm{x}}$ emissions in accordance with the evolution of the initiation of the combustion at $1500 \mathrm{rpm}$ (Fig. 11). At $2500 \mathrm{rpm}, \mathrm{NO}_{\mathrm{x}}$ values are in the Diesel fuel value variability.

Figure 27 and Figure 28 show olefin addition impact on $\mathrm{HC}$ emissions. Except for octa-1,7-diene addition at $2500 \mathrm{rpm}$ $\times \mathrm{IMEP}=3$ bar, olefin addition decreases HC emissions.

Figure 29 to Figure 31 show olefin addition impact on $\mathrm{CO}$ emissions. It is not possible to link $\mathrm{CO}$ emission evolution and olefin chemistry because the evolution changes for the four operating conditions.

\subsubsection{Summary of Olefin Effects}

1 Olefin addition decreases the physical delay of the Diesel base fuel because the distillation range of the Diesel base fuel decreases in temperature. 


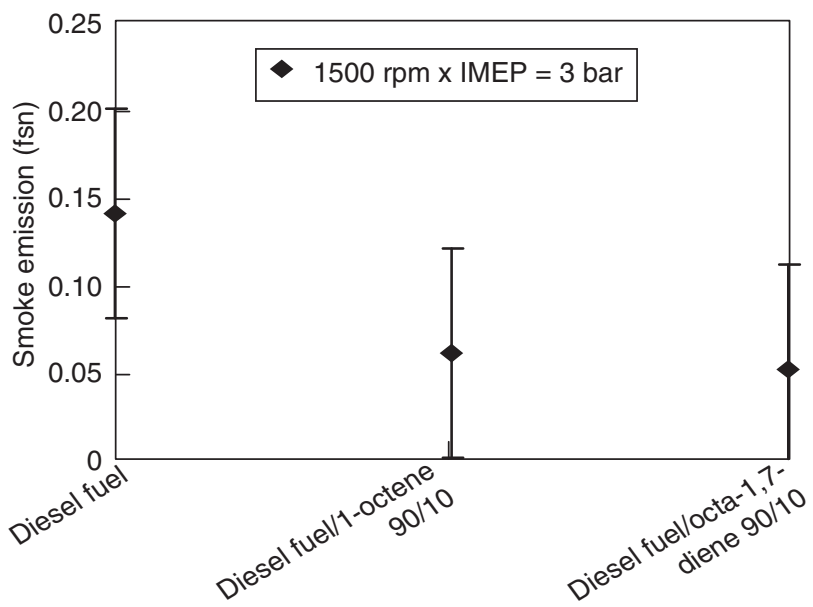

Figure 20

Olefin effect on smoke emissions at $1500 \mathrm{rpm}, \mathrm{IMEP}=3 \mathrm{bar}$.

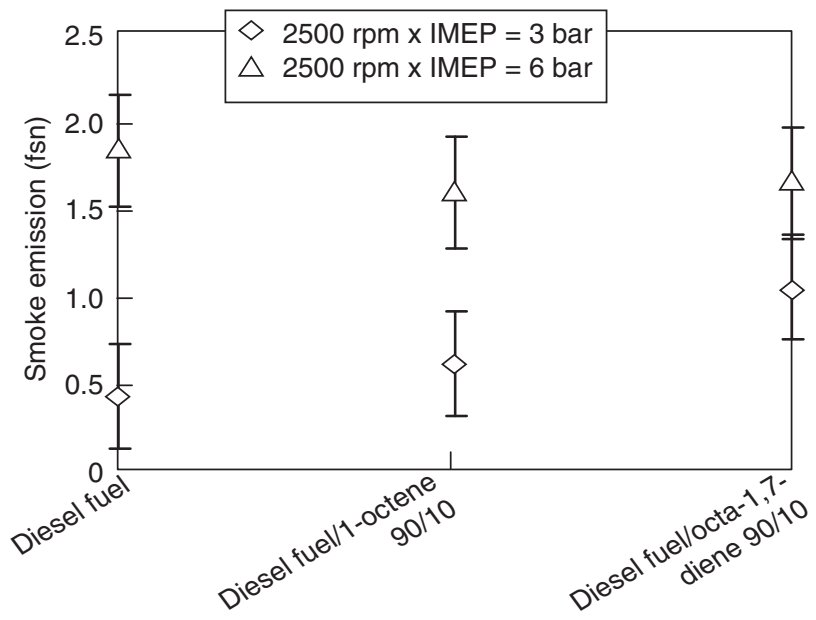

Figure 22

Olefin effect on smoke emissions at $2500 \mathrm{rpm}$.

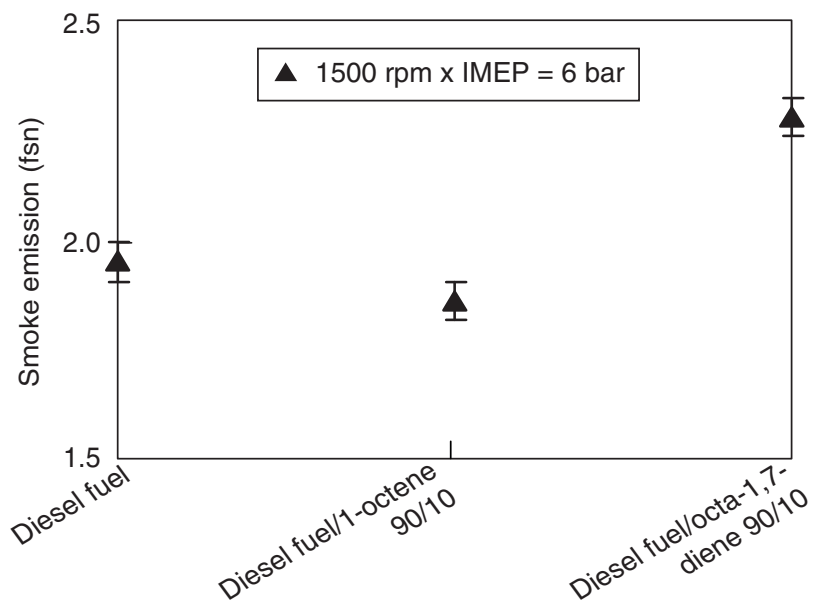

Figure 21

Olefin effect on smoke emissions at $1500 \mathrm{rpm}, \mathrm{IMEP}=6$ bar.

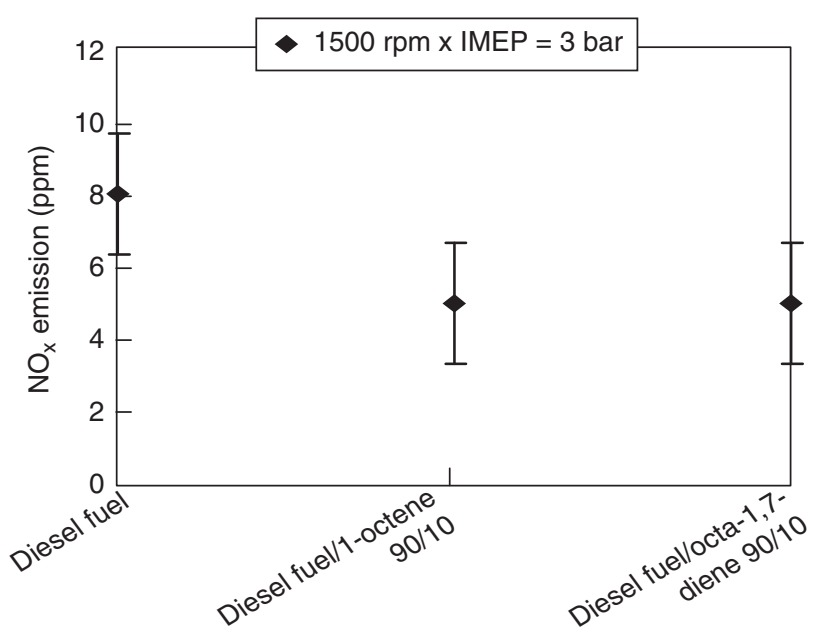

Figure 23

Olefin effect on $\mathrm{NO}_{\mathrm{x}}$ emissions at $1500 \mathrm{rpm} \times \mathrm{IMEP}=3$ bar.
2 Olefin addition increases the chemical delay (at low engine speed) of the Diesel base fuel.

3 For the combustion propagation time between the CA10 and the CA50 and the time of the end of the combustion between the peak of the HTHR and the CA90 it is difficult to explain the evolution of the results only with olefin chemistry.

4 About pollutants, olefine addition decreases HC emissions.

\section{DISCUSSION}

Olefin addition delays the initiation of the combustion of the Diesel base fuel at $1500 \mathrm{rpm}$. This can be explained by olefin chemistry.
The reaction which corresponds to the production of the cool flame is:

$$
\mathrm{RH} \stackrel{+\mathrm{O}=\mathrm{O}}{\longrightarrow} \mathrm{R}^{\circ} \stackrel{+\mathrm{O}=\mathrm{O}}{\longrightarrow} \mathrm{RO}_{2}^{\circ} \stackrel{1}{\rightarrow} \mathrm{QOOH}^{\circ} \underset{\text { and } 1}{\stackrel{\mathrm{O}=\mathrm{O}}{\longrightarrow}} \mathrm{OQ}^{\circ} \mathrm{O}+2 \mathrm{OH}
$$

\section{Reaction 1}

Reaction of the cool flame production

(RH is the hydrocarbon - 1: isomerisation).

This is a ramification process: for one radical $\mathrm{QOOH}^{\circ}$ consumes, two radicals $\mathrm{OH}^{\circ}$ are formed. 


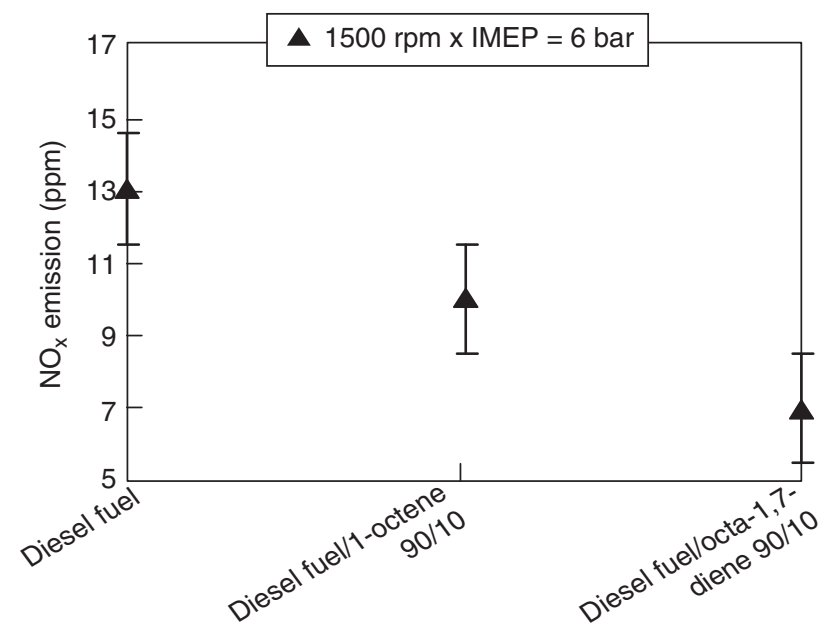

Figure 24

Olefin effect on $\mathrm{NO}_{\mathrm{x}}$ emissions at $1500 \mathrm{rpm} \times \mathrm{IMEP}=6$ bar.

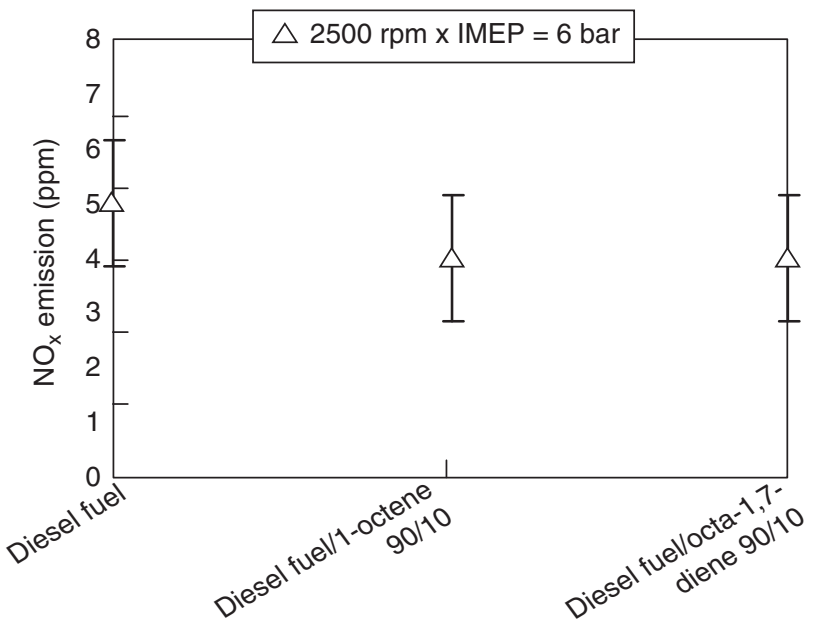

Figure 26

Olefin effect on $\mathrm{NO}_{\mathrm{x}}$ emissions at $2500 \mathrm{rpm} \times \mathrm{IMEP}=6$ bar.

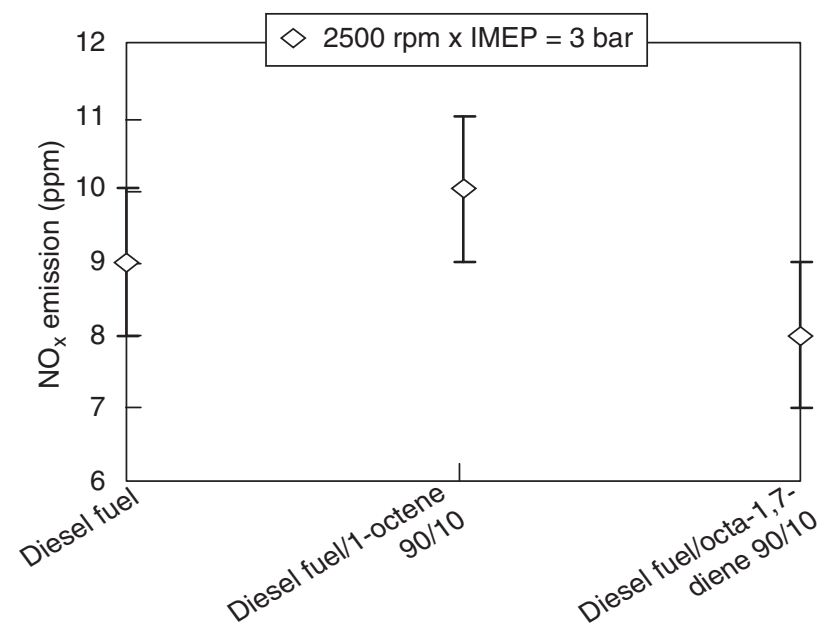

Figure 25

Olefin effect on $\mathrm{NO}_{\mathrm{x}}$ emissions at $2500 \mathrm{rpm} \times \mathrm{IMEP}=3$ bar.

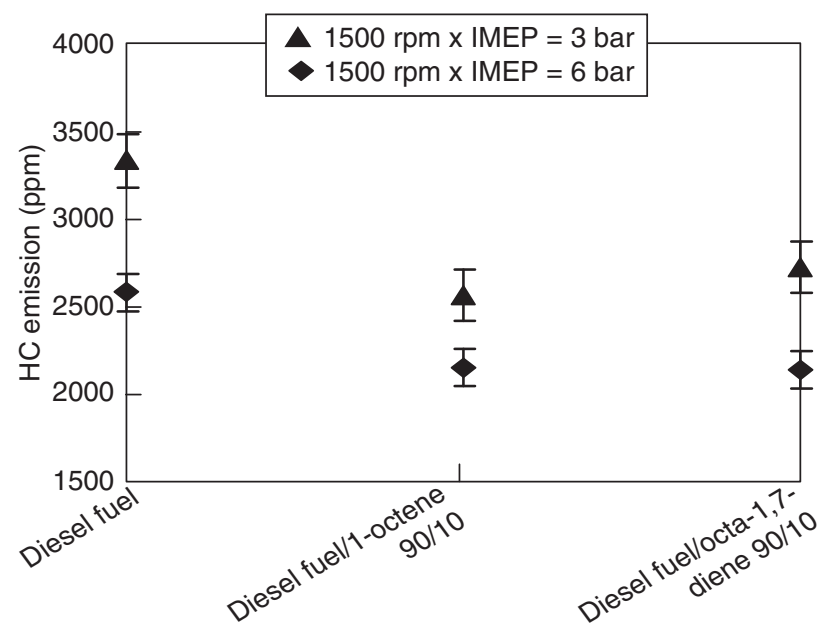

Figure 27

Olefin effect on $\mathrm{HC}$ emissions at $1500 \mathrm{rpm}$.
In the case of olefin addition, there is a double bond. This double bond implies different oxidation pathway like radical addition on the double bond [16].

Reaction 2 implies an $\mathrm{OH}^{\circ}$ addition on the double bond followed by an $\mathrm{O}_{2}$ addition; it is the Waddington's mechanism [17]. The six membered transition stage ring structure is favoured [18]. Radical R2 is a secondary radical. It is more stabilised than primary radical R1. So it is preferentially formed [19].

Reaction 2 does not occur in the paraffin chemistry because this reaction implies a radical addition on a double bond. This reaction is not a ramification process: for one radical consumed, one radical is formed so olefin addition does not yield easily to cool flame.

A second reason which can explain the decrease of the advancement of the cool flame reaction when olefins are added, is that a large percent of radicals obtained are stabilised by electron delocalisation (called mesomery) between the double bond and the radical (Reaction 3).

This is the result of the easier H-atom abstraction of the allylic hydrogens [20], Table 7. 


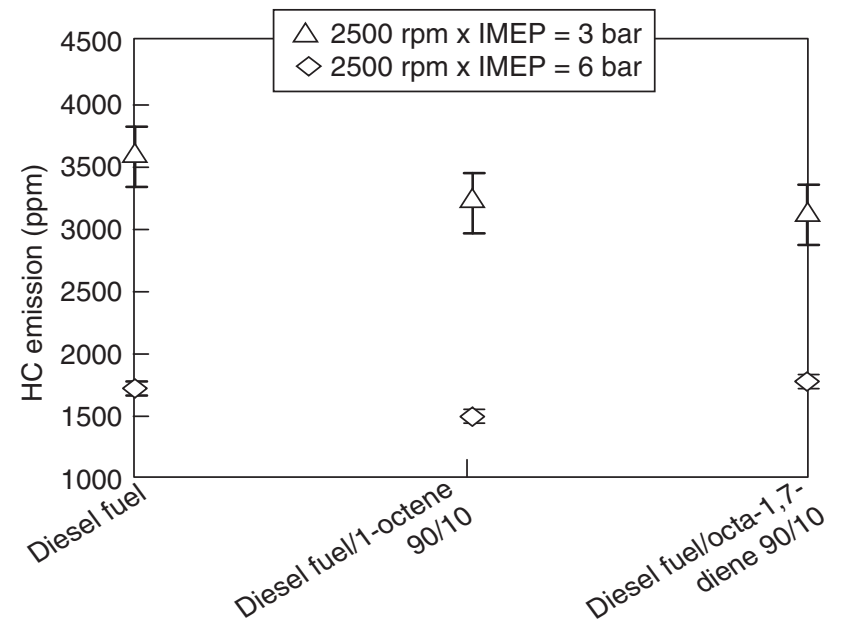

Figure 28

Olefin effect on $\mathrm{HC}$ emissions at $2500 \mathrm{rpm}$.

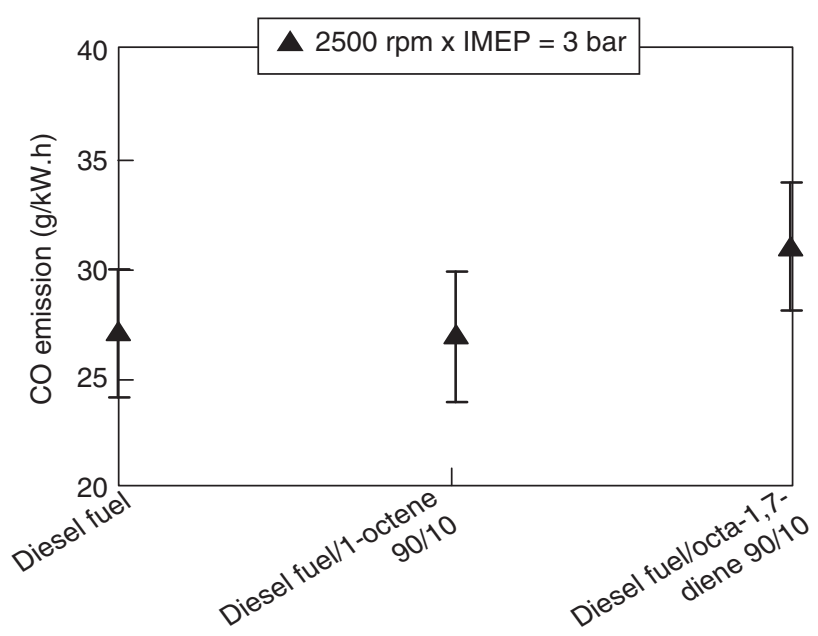

Figure 30

Olefin effect on $\mathrm{CO}$ emissions at $2500 \mathrm{rpm}$, IMEP $=3$ bar.

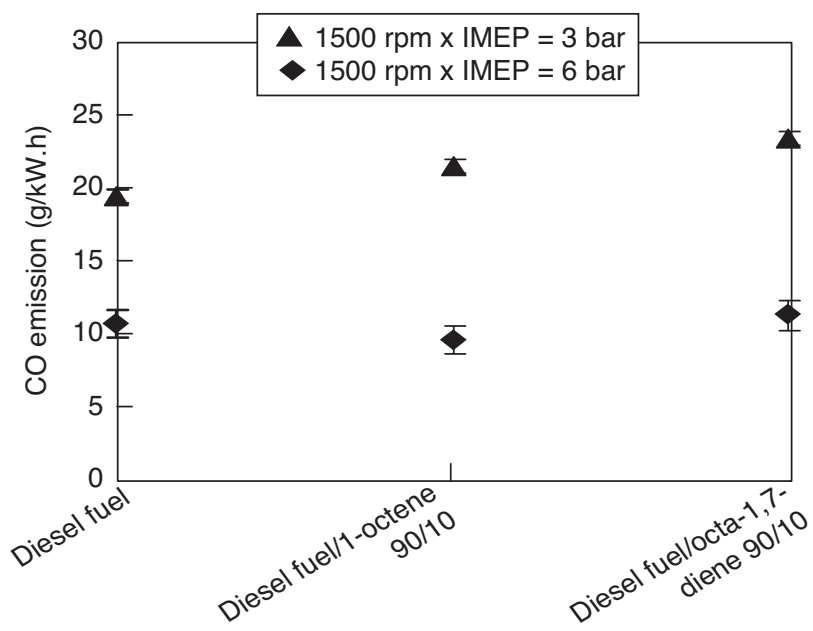

Figure 29

Olefin effect on $\mathrm{CO}$ emissions at $1500 \mathrm{rpm}$.

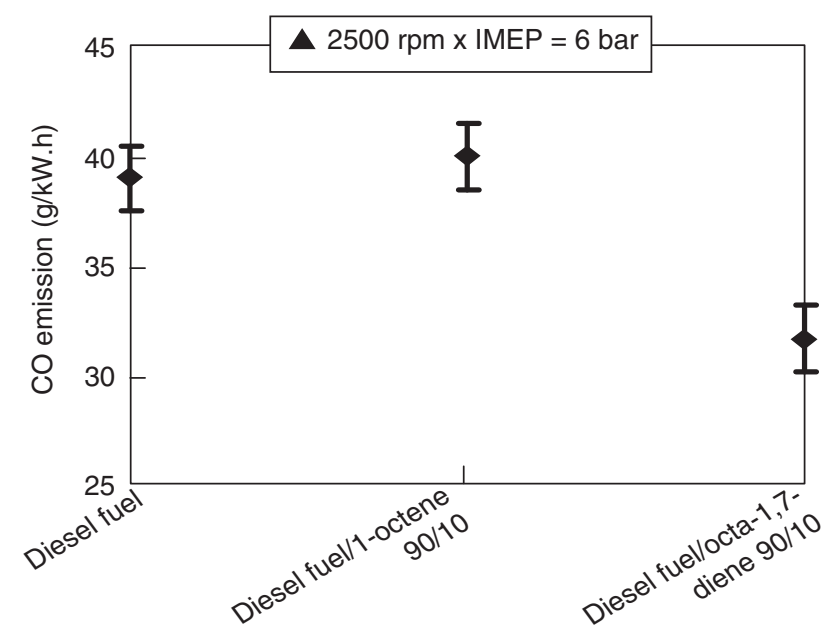

Figure 31

Olefin effect on $\mathrm{CO}$ emissions at $2500 \mathrm{rpm}$, IMEP $=6$ bar.
Table 7

Molecular bond dissociation energy of C-H

\begin{tabular}{c|c}
\hline Hydrocarbon & $\begin{array}{c}\text { Molecular bond } \\
\text { dissociation energy of } \mathrm{C}-\mathrm{H}\end{array}$ \\
\hline $\mathrm{CH}_{3} \mathrm{CH}_{2}-\mathrm{H}$ & $423 \mathrm{KJ} / \mathrm{mol}$ \\
\hline $\mathrm{CH}_{3} \mathrm{CH}_{3} \mathrm{CH}-\mathrm{H}$ & $410 \mathrm{KJ} / \mathrm{mol}$ \\
\hline $\mathrm{CH}_{3} \mathrm{CH}_{3} \mathrm{CH}_{3} \mathrm{C}-\mathrm{H}$ & $397 \mathrm{KJ} / \mathrm{mol}$ \\
\hline $\mathrm{H}_{2} \mathrm{C}=\mathrm{CH}-\mathrm{H}$ & $431 \mathrm{KJ} / \mathrm{mol}$ \\
\hline $\mathrm{H}_{2} \mathrm{C}=\mathrm{CHCH}_{2}-\mathrm{H}(\mathrm{H}$ allylic $)$ & $364 \mathrm{KJ} / \mathrm{mol}$ \\
\hline
\end{tabular}

According to the temperature and the pressure, the kinetic of the reactions varies: the reactions which control the reactivity are different.

Olefins do not work at $2500 \mathrm{rpm}$ because the mesomery and the competitive reactions "radical-double bond" do not control the reactivity (due to the temperature and the pressure). The reaction involving the cool flame (Reaction 1) controls the reactivity so olefin addition does not modify the initiation of the Diesel base fuel. 


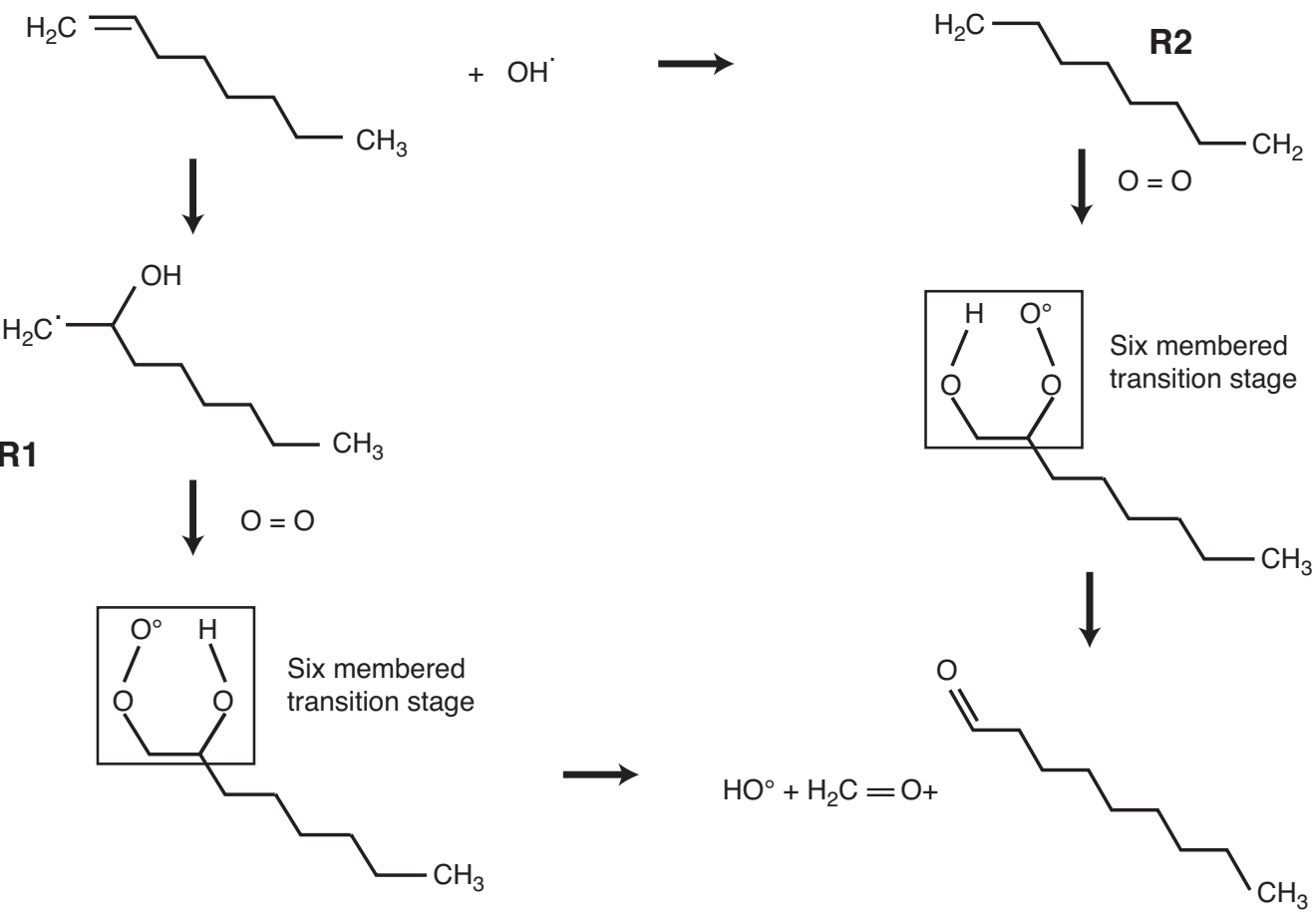

Reaction 2

Olefin oxidation pathway.

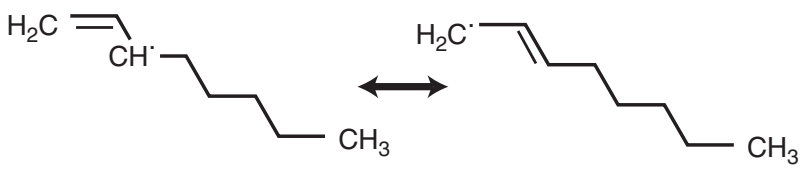

Reaction 3

Electron delocalisation for 1-octene radicals.

At $1500 \mathrm{rpm}$, the mesomery (Reaction 3) and the competitive reactions "radical-double bond" (Reaction 2 ) control the reactivity so olefin addition delays the initiation of the Diesel base fuel.

Figure 32 is a schematic summary of the results obtained.

\section{CONCLUSION}

- These experiments show the advantage of light olefin addition in a Diesel fuel. Olefin addition allows to delay the initiation of the combustion and to reduce the physical delay: the blend is more homogeneous. Also, HC emissions decrease.
- The fact that olefin addition delays the initiation of the Diesel base fuel can be explained by olefin chemistry. The competitive reactions, involving the double bond and the radical, seem to delay the initiation of the Diesel base fuel. There is also radical stabilisation by mesomery which can explain this comportment.

- Olefin addition impacts the initiation of the combustion. For the combustion propagation time between the CA10 and the CA50 and the time of the end of the combustion between the peak of the HTHR and the CA90, it is difficult to explain the results only with olefin chemistry. Other works are needed to visualise the link between the chemistry of the fuel and the combustion between the CA10 and the CA90.

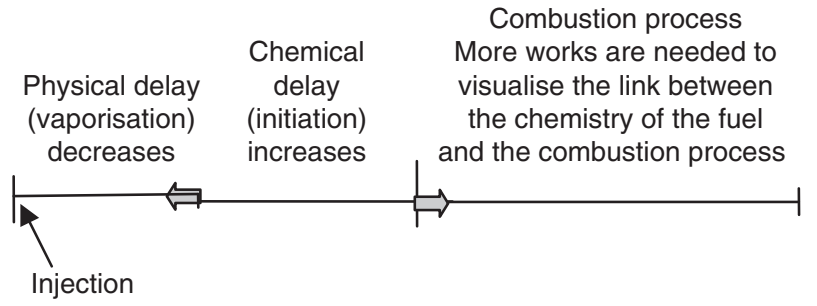

Figure 32

Schematic representation of the results obtained with olefin addition. 


\section{ACKNOWLEDGMENTS}

The authors wish to thank G. Roy for the engine experiments. D. Alseda thanks ANRT for a doctoral grant.

\section{REFERENCES}

1 Jeuland N., Montagne X., Duret P. (2003) Engine and fuel related issues of gasoline CAI (Controlled Auto-Ignition) combustion, SAE paper 2003-01-1856.

2 Aroonsrisopon T., Sohm V., Werner P., Foster D.E., Morikawa T., Lida M. (2002) An investigation into the effect of fuel composition on HCCI combustion characteristics, SAE paper 200201-2830.

3 Yamasaki Y., Lida N. (2000) Numerical simulation of auto-ignition and combustion of n-butane and air mixtures in a 4-stroke HCCI engine by using elementary reactions, SAE paper 200001-1834.

4 Dec J.E. (2002) A computational study of the effects of low fuel loading and EGR on heat release rates and combustion limits in HCCI engines, SAE paper 2002-01-1309.

5 Sjöberg M., Dec J.E. (2003) Combined effects of fuel-type and engine speed on intake temperature requirements and completeness of bulk-gas reactions for HCCI combustion, SAE paper 2003-01-3173.

6 Kelly-Zion P.L., Dec J.E. (2000) A computational study of the effect of fuel type on ignition time in homogeneous charge compression ignition engines, Proceeding of the Combustion Institute, Vol. 28, pp. 1187-1194.

7 Aceves S.M., Flowers D., Martinez-Frias J., Espinoza-Loza F., Pitz W.J., Dibble R. (2003) Fuel and additive characterization for HCCI combustion, SAE paper 2003-01-1814.

8 Bessonette P.W., Schleyer C.H., Duffy K.P., Hardy W.L., Liechty M.P. (2007) Effects of fuel property changes on heavyduty HCCI combustion, SAE paper 2007-01-0191.

9 Hiltner J., Agama R., Mauss F., Johansson B., Christensen M. (2003) Homogeneous charge compression ignition operation with natural gas: fuel composition implications, J. Eng. Gas Turb. Power 125.
10 Lü X., Hou Y., Ji L., Zu L., Huang Z. (2006) Heat release analysis on combustion and parametric study on emissions of HCCI engines fueled with 2-propanol/n-heptane blend fuels, Energy Fuel 20, 1870-1878.

11 Lü X., Ji L., Zu L., Hou Y., Huang C., Hung Z. (2007) Exermental study and chemical analysis of n-heptane homogeneous charge compression ignition combustion with prot injection of reaction inhibitors, Combust. Flame 149, 261-270.

12 Kawano D., Suzuki H., Ishii H., Goto Y., Odaka M., Murata Y., Kusaka J., Daisho Y. (2005) Ignition and combustion control of diesel HCCI, SAE paper 2005-01-2131.

13 Dagaut P., Reuillon M., Cathonnet M. (1994) High pressure oxidation of liquid fuels from low to high temperature. $1 \mathrm{n}$-Heptane and iso-Octane, Combust. Sci. Technol. 95, 233-260.

14 Dagaut P., Cathonnet M., Rouan J.P., Foulatier R., Quilgars A., Boettner J.C., Gaillard F., James H. (1986) A jet-stirred reactor for kinetic studies of homogeneous gas-phase reactions at pressures up to ten atmospheres ( 1 MPa), J. Phys. E Sci. Instrum. 19, 207-209.

15 Walter B., Gatellier B. (2003) Near zero $\mathrm{NO}_{\mathrm{x}}$ emissions and high fuel efficiency diesel engine: the NADI ${ }^{\mathrm{TM}}{ }^{\mathrm{x}}$ concept using dual mode combustion, Oil \& Gas Sci. Technol. - Rev. IFP 58, 1, 101-114.

16 Minetti R., Roubaud A., Therssen E., Ribaucour M., Sochet L.R. (1999) The chemistry of pre-ignition of n-pentane and 1-pentene, Combust. Flame 118, 213-220.

17 Leppard W.R. (1989) A comparison of olefin and paraffin autoignition chemistries: a motored-engine study, SAE paper 892081 .

18 Ribaucour M., Minetti R., Sochet L.R., Curran H.J., Pitz W.J., Westbrook C.K. (2000) Ignition of isomers of pentane: an experimental and kinetic modeling study, Proceeding of the Combustion Institute, Vol. 28, pp. 1671-1678.

19 Allinger N.L., Cava M.P., Jonhson C.R., De Jongh D.C., LeBel N.A., Stevens C.L. (1980) Chimie organique, Tome 1 Structure des molécules, Édition Universitaire.

20 Shibata G., Oyama K., Urushihara T., Nakano T. (2005) Correlation of low temperature heat release with fuel composition and HCCI engine combustion, SAE paper 2005-01-0138.

Final manuscript received in February 2008 Published online in July 2008 or distributed for profit or commercial advantage and that copies bear this notice and the full citation on the first page. Copyrights for components of this work owned by others than IFP must be honored. Abstracting with credit is permitted. To copy otherwise, to republish, to post on servers, or to redistribute to lists, requires prior specific permission and/or a fee: Request permission from Documentation, Institut français du pétrole, fax. +33147527078 , or revueogst@ifp.fr. 